\title{
The potential of parrotfish faeces in replenishing reefs with coral-associated microbiome
}

Trigal M. Velásquez-Rodríguez ${ }^{1}$, Catalina Zuluaga-Arias ${ }^{1}$, Sandra M. Montaño-Salazar ${ }^{1,3}$, John M.

${ }^{[1]}$ Laboratorio de Biología Molecular Marina-Biommar, Departamento de Ciencias Biológicas, Universidad de los Andes, Bogotá, Colombia.

${ }^{[2]}$ Laboratorio de Ciencias Básicas Médicas, Facultad de Medicina, Universidad de los Andes, Bogotá, Colombia

${ }^{[3]}$ Facultad de Ciencias, Universidad Nacional de Colombia, Bogotá, Colombia

\section{Contact info}

$11 *$ Correspondence author: juansanc@,uniandes.edu.co

\section{Keywords}

14 Sparisoma viride, coral microbiome, Symbiodinaceae, environmental reservoirs

\section{Abstract}

Sparisoma viride is the most abundant parrotfish in the Caribbean and is considered as the most important excavator due to corallivore behaviour. Parrotfishes are a keystone group that favour the growth and resilience of coral reefs removing macroalgae and structuring the benthic communities. The microbial symbiotic communities are involved in multiple functions related to nutrition and immunity maintaining corals health. Because $S$. viride scrape coral tissues, the skeleton and the algae on coral, it could be important reservoirs or vectors of microorganism for the corals through the faeces dispersion, however,

23 the role of parrotfishes as reservoirs are poorly studied. Establishing microbial communities present in

24 parrotfish faeces will contribute to understand the ecological impact of parrotfishes in coral resilience. We

25 investigated the composition of disseminated bacteria and the extent to which the cell integrity of

26 dinoflagellate photosymbionts (Symbiodiniaceae) is maintained in the faeces and compare with sediments

27 and water column controls. Then, we analysed diversity and structure of bacterial communities at family

28 level and search similarities between faeces of the study and coral associated microbiome reported in the

29 literature. Similar levels of structural integrity and photosynthetic health of Symbidiodinaceae cells were

30 found in both faeces and reef sediments. Besides, the sediments microbiome echoes the parrotfish faecal

31 microbiome by sharing high diversity and a similar bacterial community composition. Several bacterial

32 families were present in parrotfish faeces and in coral microbiome reported in the literature highlighting

33 the dispersal potential of parrotfishes replenishing coral reefs. Despite the sampling limitations, these

34 findings uncover the potential role of the excavator parrotfish in enriching environmental reservoirs, 
35 especially reef sediments, with coral-associated bacteria and photosynthetic microalgae. Parrotfishes could reinforce the coral microbiome and facilitate coral symbiont acquisition, key features critical to maintaining the fitness of one of the most threatened ecosystems on Earth. This finding could be considered as a first step in uncovering a mechanism for reef-microbiome maintenance.

\section{Introduction}

The coral microbiome includes species-specific symbiotic interactions with unicellular dinoflagellates of the family Symbiodiniaceae, endolithic green algae, bacteria, archaea, fungi, protists and viruses (Ricci et al. 2019). From the surface mucus layer into the skeleton, coral-associated bacterial communities and photosynthetic dinoflagellates support coral homeostasis (Ainsworth et al. 2015). Bacteria occupy specific niches in the coral according to their function at the intracellular and perialgal space (Hernandez-Agreda et al. 2017), where critical roles in catabolizing organic matter and recycling nutrients are performed (Bourne et al. 2016). Particularly, bacteria located in the coral mucus supply nutrition while protecting against pathogens and UV light, which is an emerging and dynamic process from the constant environmental interaction (Bourne et al. 2016). In addition, they produce diffusible and non-diffusible antibacterial compounds that, along with physical exclusion, regulate other bacterial populations influx

Acquisition of symbiotic dinoflagellates and bacteria by corals may occur mainly by horizontal transmission from the environment, occasionally by vertical transfer to the gametes from the parent colony, or by a mixture of both (Hernandez-Agreda et al. 2017). An essential element for the uptake process is the availability of microbial components outside the host (Littman et al. 2009), especially in environmental reservoirs such as the water column (Takabayashi et al. 2012), benthic macroalgae beds (Porto et al. 2008) and sediments (Nitschke et al. 2016). Pioneering observations found corallivorous fish delivering coral symbionts to the environment (Muller-Parker 1984). In the Caribbean, the occurrence of Symbiodinaceae cells in faeces of the stoplight parrotfish Sparisoma viride, with densities up to $38.3 \times 10^{3}$ cells $\mathrm{ml}^{-1}$, has supported this notion (Porto et al. 2008; Castro-Sanguino and Sánchez 2012).

63 S. viride is the main excavating parrotfish of the Caribbean. This feeding behaviour leads to the ingestion 64 of symbionts while foraging on rock and live coral (Sanchez et al. 2004; Francini-Filho et al. 2008).

65 Notably, its primary substratum to feed is the epilithic algal matrix found on dead coral, and live coral is 66 approximately $1 \%$ of the total fish diet (Bonaldo et al. 2014). It is important to remark, which is also well67 documented in the literature, that $S$. viride targets only endolithic material for feeding (Bruggemann et al. 1994; Clements et al. 2016; Nicholson and Clements 2020). The ingestion of photoautotrophs, like 
69 Symbiodinaceae, should be considered as a by-product. Additionally, S. viride forages other benthic

70 species such as sponges (Radax et al. 2012; Burkepile et al. 2019a). After excavating, the grinding action

71 of $S$. viride pharyngeal jaws and long gut pass transforms calcium carbonate in fine sediment (Perry et al.

72 2015), which contains living Symbiodinaceae (Castro-Sanguino and Sánchez 2012) and even viable

73 macroalgae (Vermeij et al. 2013).

Coral reefs face unprecedented rates of degradation and increasing stressful scenarios (Hughes et al. 2017). Uncovering processes and mechanisms to enhance ecological resilience is crucial in addressing this crisis (Chung et al. 2019). Moreover, abundance declining in key species such as S. viride (Near Threatened - IUCN Red List) is threatening the ecological input for local resilience. On this basis, we hypothesized that the dispersal of coral microbiome components is influenced by $S$. viride faeces suggesting a coral reef microbiome maintenance mechanism, which is important to maintain the environmental reservoirs of microbial communities that are key on coral reefs.

\section{Materials and Methods}

\section{Data and code availability}

86 The qiime2R and $\mathrm{R}$ code are available on the Github repository

87 (https://github.com/smmontanos/Microbiome-analysis-of-Parrotfish.git) with a readme. The procedures 88 are explained in the section of Methods Details.

89 Original raw sequences of the bacterial communities associated with the samples of the study were deposited in NCBI short read sequences (SRA) under the Bioproject PRJNA623459.

\section{Study Area}

93 The fieldwork was carried out in the Archipelago of San Andrés, Old Providence, and Santa Catalina

94 (Southwestern Caribbean), which is composed of oceanic islands, submerged banks, and atolls located

95 approximately $800 \mathrm{~km}$ northwest of Colombia. This territory is part of the Seaflower Biosphere Reserve

96 declared by UNESCO in 2005 and is considered the largest Marine Protected Area (MPA) in the

97 Caribbean. Seaflower MPA is relevant at global scale as it contains over 200.000 ha of productive open-

98 ocean reefs and extended reefs associated with diverse ecosystems (The CaMPAM Mapping Project,

99 2017), whereby it is regarded as the third largest barrier reef worldwide. Specifically, this study was

100 developed around San Andrés Island which has $15 \mathrm{~km}$ of long barrier reef (The CaMPAM Mapping

101 Project, 2017). The sampling was conducted at Nirvana Diving Site in $12^{\circ} 30^{\prime} 05^{\prime \prime} \mathrm{N}$ and $81^{\circ} 43^{\prime} 56^{\prime \prime} \mathrm{W}$

102 and West Point reef at the site located in the coordinates $12^{\circ} 31^{\prime} 15.45^{\prime \prime} \mathrm{N}, 81^{\circ} 43^{\prime} 48.60^{\prime \prime} \mathrm{W}$ along the 
103 leeward reef of the island ("Fig. S1"). Sampling was possible thanks to the research permit No00254

104 (2017) issued by Autoridad Nacional de Licencias Ambientales (ANLA), Ministerio de Medio Ambiente

105 y Desarrollo Sostenible, Colombia

\section{Symbiodinaceae Faeces sampling}

108 Observational samplings of focal male adult individuals (terminal phase) of $S$. viride were conducted

109 using SCUBA diving in a total area of $5.000 \mathrm{~m}^{2}$, consisting of patch reefs (depth 3 to $12 \mathrm{~m}$ ). The

110 standardized time for focal observations was 10 minutes per individual; preferred individuals were those

111 foraging near to the bottom due to the consistent quality of the faeces released. During this time, one pellet

112 faeces sample per individual was collected immediately after released on substrate using $10 \mathrm{ml}$ syringes,

113 intensely procuring pellet material only. A total of 40 pellet faeces samples were collected. Additionally,

114 sediment control (seabed) samples were taken (60 cm horizontally to the pellet faeces fall place). Each

115 syringe was disposed in a Ziploc bag marked with the sample type and safely kept. After the immersion,

116 samples were fixed in formalin $10 \%$ to preserve cell integrity. This sampling was developed during June

117 2016. Underwater time corresponded to 24 diving hours.

\section{Faeces filtration}

120 In the laboratory, each sample was filtered using a plastic Büchner funnel coupled with a vacuum pump 121 and a previously weighted Whatman filter paper grade 4 (25-30um mesh size). Sample scattered on the 122 filter paper was washed with 0.22 um Filtered Sea Water (FSW) until recovering a final volume of $50 \mathrm{ml}$.

123 After, the filter was dried at room temperature, and its new weight with the sample sediment retained on it

124 was registered. Symbiodinaceae cells size ranged from 5 to $20 \mathrm{um}$, and therefore, it was expected to

125 recover them the filtrate. Each $50 \mathrm{ml}$ falcon tube was centrifuged at $3100 \mathrm{rpm}$ for $5 \mathrm{~min}$. Subsequently, the

126 pellet was resuspended into $250 \mathrm{ul}$ of FSW. The difference between the blank filter paper and the dried

127 sediment sample on filter paper was considered as the collected faeces' weight dry sediment. This process

128 was applied to the control samples as well. Filtered samples were protected from light incidence due to the

129 possible autofluorescence degradation of Symbiodinaceae cells.

\section{Microscopy verification and enumeration}

132 Microscopic observation to verify the presence of Symbiodinaceae cells was carried out on an Improved

133 Neubauer haemocytometer (Hausser Scientific, USA), under a compound light microscope Olympus

134 CX21, using 40X magnification. Symbiodinaceae recognition was based on previous observations of

135 tissue samples and zooxanthellae extruded from Pterogorgia guadalupensis, and from published

136 identification photos on scientific papers. Thus, cells were identified using characters as unicellular 
137 circular shape, golden-brownish colour, elongated and reticulated chloroplast and large pyrenoid body

138 (MR. Nitschke, doctoral dissertation and personal communication, 2015).

140 Viability quantification by flow cytometry

141 FCM Standardization. Quantification of viable cells (high fluorescence) and degrading/unviable cells

142 (low fluorescence) of Symbiodinaceae in $S$. viride faeces was carried out by flow cytometry (FCM). First,

143 it is important to note that viability was not based on fluorescence intensity only. Although Chl

144 autofluorescence may prevent the separation between viable and apoptotic cells (Strychar et al. 2004), low

145 Chl fluorescence is related to stressed or damaged Symbiodinaceae (Gierz et al. 2020), which cell

146 morphology can be accurately spotted using FCM measurements emitted by particles digitalized as: first,

147 thanks to the forward scatter (FSC) or the signal related to the cell size and shape; and second, due to side

148 scatter (SSC) or the signal indicative of cell granularity. Based on FSC and FSC, parameters are specific

149 to each particle type, FCM identifies cell populations composed of the same particle types. Moreover,

150 FCM identifies cells populations based on: first, particles light scattering principles, and second the

151 excitation and emission of fluorescence; both as the response to a light beam. In detail, a cell solution

152 enters into the sample injection probe, in which there is a stable stream (generally PBS solution) that

153 forces each particle to pass individually. During the travel, each particle passes through a flow cell, the

154 site in which is stimulated using laser illumination (488 nm or $633 \mathrm{~nm}$, BD FACs Canto II, BD). As a

155 result, the particle emits a response expressed in two measures of light scattering that are detected and

156 converted into electrical signals by a light detector.

158 For FCM standardization purposes, preliminary assays were developed using two different samples types;

159 first Pterogorgia guadalupensis, a common zooxanthellate octocoral in the study area, extracts from live

160 tissue, and second, P. guadalupensis zooxanthellae cultures aliquots. In the beginning, the process

161 consisted in differentiating cellular components from debris particles based on FSC and SSC. Both

162 parameters indicated heterogeneous size of cellular components in samples. In the next stage, cellular

163 components were distinguished using fluorescence emission. For this, propidium iodide (PI) staining was

164 performed to both types of samples as a way of promoting fluorescence resolution for cell viability

165 quantifications; however, there were not observed significative differences in fluorescence, in comparison

166 to unstained samples. Consequently, it was concluded that Symbiodinaceae autofluorescence signal was

167 pertinent as a viability quantification criterion. In this way, a red fluorescence threshold set (670 nm long-

168 pass), related to Symbiodinaceae autofluorescence was established after testing the efficiency of three

169 different PMT (520 nm long-pass, $590 \mathrm{~nm}$ long-pass and $670 \mathrm{~nm}$ long-pass) in cells differentiation.

170 Finally, cells populations in faeces and sediment samples were gated and counted using FCS, SSC and 
171 fluorescence parameters between particles. Subsequently, sorting (FACs ARIA II, BD) was carried out on

172 the individual defined populations. After, each sorted population was observed using an Improved

173 Neubauer haemocytometer and photographic images were taken. Additionally, fluorescence microscopy

174 observations were done to corroborate light microscopy findings. Based on the sorted population results,

175 the FCM settings were considered standardized for the S.viride faeces viability quantification.

176 FCM conditions for viability quantification S. viride faeces samples and sediment controls filtered were

177 analyzed using a BD FACS Canto II cytometer, coupled with the FACS Diva 6.1. Software. A sample

178 volume of $200 \mathrm{ul}$ was used for each run, and a total of 1500-2000 cell events were registered. FSC and

179 SSC were collected using a $488 \mathrm{~nm}$ band-pass filter, with blue light of origin. Additionally,

180 Symbiodinaceae red autofluorescence signals (chlorophyll a) were collected via 670nm band-pass filter.

181 As a conclusion, FSC and SSC, in combination with the Symbiodinaceae endogenous autofluorescence

182 were used to discriminate zooxanthellae population from macroalgae fragments, non-algal cells and high

183 quantity of debris in S.viride faeces. The same parameters functioned for the differentiation of

184 Symbiodinaceae viable cells and degrading/unviable cells. Normalization of data was made for assuring

185 an accurate comparison of cell size, fluorescence patterns and viability percentages between populations

186 in the total samples. Details used for the FCM analysis, under logarithmic criterion, were

187 (parameter/voltage): FSC/220, SSC/222, FITC/560, PE/500, PE/500 and PE-Cy7/600.

\section{Statistical Analysis for Symbiodinaceae cells}

189 Viability quantification data were analysed for normality. Multifactorial ANOVA was used for examining

190 significance of Symbiodinaceae viability vs. non-viability in S. viride faeces, and in contrast to sediment

191 controls. Additionally, the Person Correlation Coefficient was calculated for testing the correlation

192 between healthy and non-healthy Symbiodinaceae populations vs. milligrams of faeces dispersed.

193 FCM Method

194 During the standardization process, three cell populations were gated: P1 (red), P2 (green) and P3 (blue)

195 in a dot plot ("Fig.S2"). Additionally, it was determined an ungated population containing mainly

196 sediment, which hereinafter will be referred to as P4 (black). According to the populations' distribution,

197 P2 was identified as the one characterized by higher fluorescence signal emission, size and granular cells

198 content. Besides, P3 showed a lower fluorescence signal than P2, and granular cells too; P1 presented the

199 lowest fluorescence signal vs. P2 and P3; and P4 exhibited non-cellular components or debris as it was

200 previously mentioned. Additionally, fluorescence microscopy observations to sorted populations were

201 coherent with the previous light microscopy findings. In this sense, P2 contained Symbiodinaceae cells

202 that presented the highest fluorescence emission; P3 presented zooxanthellae cells with less fluorescence

203 emission in contrast to P2; and finally, P1 and P4 components emitted the lesser fluorescence ("Fig.S4").

204 Light and fluorescence observations in sorted populations supported the validation of FCM standardized 
parameters. S. viride faeces and control sediment samples were observed under light microscopy to register Symbiodinaceae presence. Zooxanthellae cells were confirmed in $100 \%$ of the samples and controls collected. In all cases, cells were observed coccoid in shape with 11-13 um of diameter. Dividing cells stages were evidenced in faeces samples. Intracellular composition patterns varied from welldeveloped and elongated chloroplasts and defined pyrenoid body to few recognizable organelle's presence. Additionally, the colour pattern observed corresponded to golden brownish cells to translucent appearance.

\section{Viability quantification by flow cytometry}

213 Accordingly, to FCM standardized settings, the three gated populations and the ungated population

214 validated were identified and quantified in all $S$. viride faeces and sediment controls (figure 1 in the main

215 text). An entire Symbiodinaceae population per sample was defined as the sum of P2 (viable) and P3

216 (degrading/unviable) events. Thus, 22855 healthy events were registered in P2 vs. 7500 healthy ones in

217 P3. Regarding faeces or sediment control $\mathrm{mg}^{-1}$, a total of 62 healthy events $\mathrm{mg}^{-1}$ corresponding to P2 were

218 detected, and in contrast, 32 healthy events $\mathrm{mg}^{-1}$ in $\mathrm{P} 3$ were evidenced. This fact means a proportion of 2

219 healthy cells events registered in faeces samples to 1 healthy cell event in sediment control. Conversely,

$220 \mathrm{P} 1$ and P4 data were not included in the analyses due to the absence of zooxanthellae in them. In this

221 context, Symbiodinaceae viability calculation per sample was estimated based on the relation between P2

222 events and the total cells population frequency, expressed as a percentage. The same calculation was done

223 for the estimation of the percentage of degrading/unviable cells (see raw data in "Table S1").

\section{Microbiota in faeces sampling}

The microbial component was sampled in West point reef. The sampling was developed in August 2019.

228 Faeces samples were collected in situ through SCUBA diving. Focal Sparisoma viride individuals were followed until they defecated. One sample was collected per individual using a $50 \mathrm{~mL}$ syringe immediately after the deposition and stored in an individual Ziploc bag. Additionally, sediment control (seabed) samples were collected right next to the faeces deposition. Lastly, three water controls and three

232 sand channel samples were taken aleatorily within the area of study. Water samples were filtered in a 0.2 233 microns filter. All samples and filters from water samples were transfer to individual testing tubes with 234 ethanol at $70 \%$ to preserve bacteria until DNA extractions in laboratory conditions. A total of 12 faeces 235 samples, 12 sediment samples, three water column samples (controls) and three sand channels samples 236 (controls) were collected.

\section{DNA extraction and 16S rRNA gene Sequencing}


DNA extraction was made using the Quick DNA Fecal/Soil Microbe Kits by Zymo Research according to manufacture instructions. DNA extractions were sent to the Iowa State University (DNA facility) for library preparation and sequencing on the Illumina Miseq Platform. The desired region for amplification was the V4 hypervariable region of the 16S rRNA gene using the primer pairs 515F and 806R(Caporaso et al. 2011).

\section{S rRNA based community analysis}

246 Qiime 2 version 2018.4 was used for bioinformatics analysis with different implemented plugins (Bolyen et al. 2019). Amplicon sequence variants (ASVs) were chosen to work with because they provide better resolution than OTUs based methods(Callahan et al. 2017). First, DADA2 plugin(Callahan et al. 2016) was used for quality control and noise reduction (-p-trim-left-r 0 -p-trim-left-r 0 -p-trunc-len-f 238 -ptrunc-len-r 232). These parameters were chosen according to the reads quality distribution along the length of the sequence. To assess which microbial taxa were present in the samples, we used to q2-featureclassifier plug in to classify our ASVs taxonomically. The reference database used was SILVA 132, specific for 515F and 806R region (http://qiime.org/home_static/dataFiles.html). Next, mitochondria, chloroplast and eukaryotic sequences were removed and a filter of minimum frequency of 17 for the ASVs was applied. These filtered sequences were used to construct the phylogenetic tree, which was made using FastTreeMP with MAFFT alignment implemented in qiime2. The bacterial composition of the environmental controls, water column and sand channels, as well as of sediments and $S$. viride faeces, were graphed using the produced table by the script qiime taxa collapsed at family level. Subsequently, the result was graphed using sunburst multilevel pie charts in excel. In order to analyse the diversity of each treatment ( $S$. viride faeces, reef sediments, water column and sand bank), we used the package phyloseq (McMurdie and Holmes 2013), implemented in R v 3.5. In addition, we examined the differences between samples richness (Chao1) using ANOVA and Tukey test ("Table S2"). The richness bloxplots were graphed using the package ggplot2(Wickham 2009). For beta diversity a non-metric multidimentional scaling (NMDS) analysis was done using Bray Curtis dissimilarities. A PERMANOVA was performed ( 999 permutations) in phyloseq to determine differences in the composition of bacterial communities and PERMADISP was performed (999 permutations) to test of multivariate dispersions. our findings of the faecal microbiome of $S$. viride, were used to elaborate the Venn diagram found in Figure 3.B.

\section{Results and discussion}




\section{$S$. viride faeces enriches reef sediments with viable Symbiodinaceae cells}

We confirmed the presence of Symbiodinaceae cells in $100 \%$ of $S$. viride faeces and sediment controls, with an average density of 3328 cells ml$^{-1}$ for the former, and 1269 cells ml$^{-1}$ for the latter (See Fig. 1 and Table S1, Fig. S2-4). In general, viable cells in S. viride faeces corresponded to $25.97 \% \pm 1.50$, whereas degrading/unviable cells accounted for $74.03 \% \pm 1.50$ (Fig. 1). Similarly, at sediment controls $22.24 \% \pm$ 5.36 were viable cells while $77.76 \% \pm 5.36$ corresponded to degrading/unviable cells. The percentages of viable and degrading/unviable cells were significantly different in $S$. viride faeces ( $\mathrm{F}=481.2, p<0.001)$. Contrastingly, no significant differences in the percentage of viable cells were found between $S$. viride faeces and sediment controls ( $\mathrm{F}=0.1, p>0.7$; Fig. 1). Noticeable, no correlation was observed between the percentages obtained in $S$. viride faeces and control samples vs. dry mass collected $\left(\mathrm{R}^{2}=0.023, \mathrm{~F}=1.067\right.$, $p>0.307$ ), which means that the cell integrity values were not explained by the sample's mass. Based on these patterns, we propose that $S$. viride may act as a key vector to enrich reef sediments with Symbiodinaceae cells. Therefore, we suggest that $S$. viride's faeces are crucial for maintaining the main environmental reservoir of dinoflagellates coral symbionts, in accordance to the critical role of sediments for the uptake of symbionts by corals (Adams et al. 2009; Nitschke et al. 2016).

\section{S. viride disperses a highly diverse bacterial community in reef sediments}

We analysed $16 \mathrm{~S}$ rRNA to characterize the bacterial community in $S$. viride faeces and controls. The sediments and feces showed the highest bacterial diversity followed by controls, sand channels and water column samples (Fig. 2a). Alpha diversity index demonstrated that richness of bacterial communities was significantly different between the four types of samples (ANOVA F=9.1, $p<0.001$, Table S2) where sediments and feces present similar richness $(\mathrm{p}=0.308)$ and feces differ from controls, the sand channels $(\mathrm{p}=0.03)$ and water column $(\mathrm{p}=0.01)$ samples. The differences in bacterial composition were assessed using Bray-Curtis dissimilarities in nMDS (Fig. 2b). Particularly, S. viride and sediments grouped together and were significantly different from controls (PERMANOVA, F=5.14, $\mathrm{R} 2=0.33, p=0.001$ ). Moreover, non-significant differences in the homogeneity of multivariate dispersion were showed between types of

302 samples (PERMADISP, $\mathrm{p}>0.05$ ).

303 Additionally, Proteobacteria was the most abundant phylum in all the samples with Gammaproteobacteria

304 and Alphaproteobacteria as the dominant classes. This dominance was followed by the phyla

305 Bacteroidetes, Fusobacteria, Firmicutes and Cyanobacteria in both $S$. viride faeces and sediments, and 
307 families of Gammaproteobacteria, S. viride faeces were dominated by Vibrionaceae (42.1\%) and 308 followed by Rhodobacteraceae (6.33\%), Fusobacteriaceae (5.53\%), Shewanellaceae (4.48 \%) and 309 Woeseiaceae (4.29\%). In contrast, S. viride faeces were deficient in Alphaproteobacteria. The

310 Gammaproteobacteria in sediments belonging to Rhodobacteraceae (14.52\%) and Vibrionaceae (14.36

$311 \%)$ were the most abundant families while Halieaceae (6.31\%) and Woeseiaceae (6.06 \%) were less

312 represented. We also found the family Cyclobacteriaceae from Bacteroidetes phylum (6.97\%) in the

313 sediments. Although $S$. viride faeces and sediments differed in families abundance, there were similarities

314 in the overall families identified for both types of samples (Figure 3a). Contrarily, the water column ("Fig.

315 S5") showed higher abundance of bacteria belonging to Phycisphaeraceae (24.07\%), Sphingomonadaceae

316 (17.01\%), Pseudohongiellaceae (13.9\%), Lactobacillaceae (12.86\%), Pseudomonadaceae (11.2 \%),

317 while a lesser representation of Vibrionaceae (7.47\%) and, sand channels were dominated by

318 Desulfobulbaceae (11.48 \%), Rhodobacteraceae (11.07\%), Sphingomonadaceae (9.41\%) and

319 Arenicellaceae ( $8.58 \%$ ), that differed from faeces and sediments. In fact, it was notable the presence of

320 common amplicon sequence variants (ASVs) across the identified phyla in both faeces and sediments, as

321 it is showed in the phylogeny of the complete bacterial community (Figure 2.c). On this basis, we

322 hypothesize that $S$. viride feaces may support the enrichment of bacteria in reef sediments.

\section{S. viride faeces contain a bacterial community commonly associated with the microbiome of foraged} 325 species

326 S.viride faeces had high abundances of Gammaproteobacteria ASVs, which are usually found in

327 association with coral tissue (Bourne and Munn 2005). In particular, this bacterial class is dominant in at

328 least ten coral species excavated by S.viride (Sanchez et al. 2004; Rotjan and Lewis 2005; Mumby 2009;

329 Castro-Sanguino and Sánchez 2012; Bonaldo et al. 2014; Burkepile et al. 2019b). Eight bacterial families

330 in $S$. viride faeces are associated to coral microbiomes (Fig. 3.b).

332 Among the Gammaproteobacteria class, the family Rhodobacteraceae, which are prevalent in the 333 microbiome of Orbicella (Meyer et al. 2016) and Agaricia (Gonzalez-Zapata et al. 2018), were identified 334 in both $S$. viride faeces and sediments. As diazotrophs, Rhodobacteraceae members are involved in the 335 fixation of nitrogen in association within living coral tissue and the surface mucus layer (Lesser et al. 336 2018). Similarly, other Gammaproteobacteria metabolise bioproducts from Symbiodinaceae such 337 dimethylsulfoniopropionate (DMSP) and dimethylsufide (DMS) (Raina et al. 2009). As a result, we

338 hypothesize that $S$. viride faeces replenish reef sediments with key bacteria supporting the metabolism of 339 Symbiodinaceae symbionts. This input of Gammaproteobacteria in reefs is relevant in shaping the 340 bacterial community and producing sulphur based antimicrobial functions (Peixoto et al. 2017). 
341 Vibrionaceae was the most abundant family identified in $S$. viride faeces, and it is commonly found in the

342 microbiome of several corals and sponges (Dunlap and Pawlik 1996, 1998) (Table S3).

344 Other families found in S. viride faeces were Alteromonadaceae, Flavobacteriaceae and

345 Pseudoalteromonadaceae, which are common bacterial members associated with Porites corals (Table

346 S3). Similary, Verrucomicrobiaceae, Vibrionaceae and Rhodobacteraceae are bacterial families present

347 when the mucus is old in Porites, probably S. viride fed on this coral and disperse through the faeces,

348 however, it have to tested in further studies. On the other hand, Agaricia associates closely to

349 Vibrionaceae and Rhodobacteraceae (Gonzalez-Zapata et al. 2018), and Siderastrea, Porites and

350 Pseudodiploria maintain beneficial relationships with Alteromonadaceae (Table S3) that also are present

351 in parrotfishes of the study, suggest that parrotfish could replenish the coral reef with these symbiont

352 bacteria.

354 Besides, Epulopiscium bacteria was also found in S. viride faeces. Although, this result suggests a

355 potential positive feedback of this bacteria to $S$. viride digestion, it should be interpreted with caution in

356 parrotfishes. Epulopiscium has a major role in surgeonfish supporting the digestion of marine algae

357 (Ngugi et al. 2017). Parrotfishes are not hindgut fermenters, so the presence of Epulopiscium in the $S$.

358 viride could be ingested from sediments and deserves further study (Clements et al. 2014).

360 Understanding the ecological feedback of $S$. viride's microbial dispersal

361 Our findings suggest that $S$. viride is a vector of symbiotic dinoflagellates, which constantly provides

362 inputs of viable cells. Moreover, a role in replenishing reef sediments is hypothesize based on identifying

363 the same ratio of viable cells:unviable cells in both sediments and faeces. We also found similarities in the

364 bacterial community structure between $S$. viride faeces and reefs sediments. Both of them had diverse

365 bacterial communities and sharing composition. Likewise, our results suggested that the $S$. viride spreads a

366 bacterial community commonly associated to the microbiome of species in which the fish feeds on.

368 Parrotfish release solid pellets of fine sediment than remain for a short time after being defecated (Goatley 369 and Bellwood 2010). Dispersal occurs in territories of approximately 100 to $300 \mathrm{~m}^{2}$ (medium sized), and 370 in a daily feeding range of 50 to $800 \mathrm{~m}^{2}$ (Bruggemann et al. 1996). The dispersal of Symbiodinaceae cells 371 and bacteria allows us to start thinking about the resemblance of ecological attributes between $S$.

372 viride and herbivorous in terrestrial ecosystems. The relevance of enriching reef sediments relies on coral

373 health and resilience. Sediments enhance the coral uptake of Symbiodinaceae cells (Adams et al. 2009),

374 which is relevant for coral recruitment and health recovery after bleaching events (Adams et al. 2009; Ali 
et al. 2019), and facilitate the enrichment of the coral's ecosphere with beneficial microbes and therefore, supports coral physiological responses from microbial exchange processes (Weber et al. 2019).


Figure 1. S. viride enriches reef sediments with viable Symbiodinaceae cells

Symbiodinaceae enumeration in S. viride faeces and reef sediments. We gated two distinctive populations of Symbiodinaceae cells in both faeces and sediments. Viable cells showed an intact cell membrane with spherical nucleus, well developed and elongated chloroplasts, defined pyrenoid bodies and high fluorescence signal. Conversely, degrading/unviable cells exhibited traits such as a fragmented cell membrane, undefined cytoplasmatic material, and a lower fluorescence. A. Cell density in S. viride faeces vs. sediment control. B. Boxplot showing significant differences between the percentages of viable cells and degrading/unviable in $S$. viride faeces and sediment controls. No significant differences were observed in the percentage of viable cells in S. viride faeces and sediment controls. C-D- Flow cytometry-FCM dot plots displaying the three gated populations identified during standardization in: C. S. viride faeces, and D. 
bioRxiv preprint doi: https://doi.org/10.1101/2020.09.15.298737; this version posted January 15,2021 . The copyright holder for this preprint (which was not certified by peer review) is the author/funder, who has granted bioRxiv a license to display the preprint in perpetuity. It is made available under aCC-BY-NC-ND 4.0 International license.

390 Sediment controls. Both types of samples, faeces and sediment controls, presented viable cells (high

391 fluorescence) in P2 and degrading/unviable cells in P3. ).

392

393 
A




Bacterial taxa

Cyanobacteria Bacteroidetes

Verrucomicrobia

Alphaproteobacteria Deltaproteobacteria

Gammaproteobacteria

Planctomycetes

Chloroflexi

Firmicutes

Figure 2. S. viride disperses a highly diverse bacterial community in reef sediments

A) Microbial community richness in $S$. viride faeces (blue), sediments (light purple), water column (green) and sand channels (pink) assessed with ANOVA (P-value $=0.003), B)$ Non metrical multidimensional scaling (nMDS) using Bray Curtis dissimilarities of bacterial communities present in the four types of samples. C) Phylogenetic tree of bacterial community was constructed using maximum likelihood with FasTreeMP and MAFFT alignments. The types of samples are indicated with dots (colours correspond to the part A) above each ASVs tips of the tree. Bacterial phyla are observed as regions above each clade of the tree with different colours. In the case of Proteobacteria, the phylogeny shows the phylum divide in three-class taxonomic levels. 


\section{A}

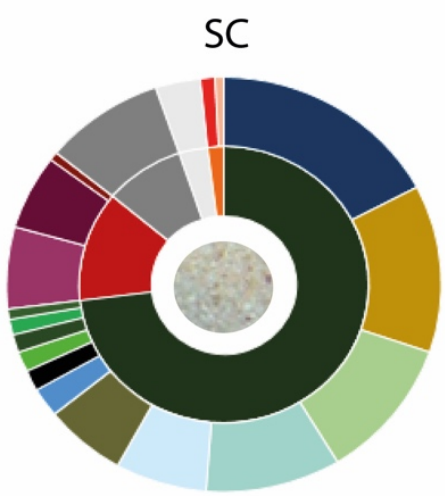

S

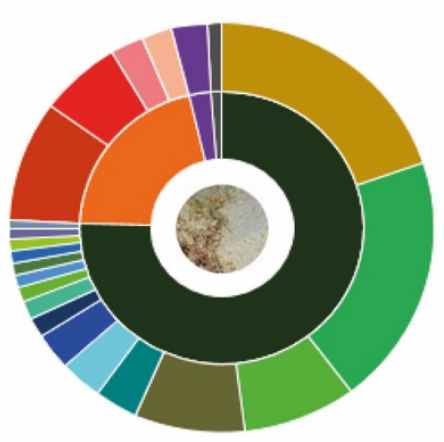

B


Phylum


407
Proteobacteria

Bacteroidetes

Cyanobacteria

Planctomycetes

- Fusobacteria

Firmicutes

Acidobacteria

Other

\section{Family}

- Vibrionaceae

- Rhodobacteraceae

- Shewanellaceae

4 Woeseiaceae

* Halieaceae

- Moritellaceae

- Fusobacteriaceae

- Geminicoccaceae

- Flavobacteriaceae

Alteromonadaceae

Rhodophirillaceae

- Cyclobacteriaceae

- Saprospiraceae

Pseudoalteromonadaceae

- Sphingomonadaceae

- Pseudohongiellaceae

Pseudomonadaceae

- Arenicellaceae

Phycisphaeraceae

- Lactobacillaceae

- Enterobacteriaceae

- Staphylococcaceae

- Xenococcaceae

Kiloniellaceae

Colwelliaceae

- Desulfobulbaceae

- Stappiaceae

- Sandarinaceae

- Hyphomonadaceae

Hyphomicrobiaceae

- Ruminococcaceae

Erysipelotrichaceae

$\square$ Nitrincolaceae

Nitrosomonadaceae

Staphylococcaceae

Thermoanaerobaculaceae

- Not assigned

Figure 3. S. viride faeces contain a bacterial community commonly associated with the microbiome

411 of foraged species

412 A) Bacterial composition at phylum and family level using pie charts. Relative abundances of ASVs

413 classified at family and phylum levels are indicated for two types of control samples which are water

414 column (WC) and sand channels (SC); and in the lower part for the microbiota associated with reefs

415 sediments (S) and S. viride faeces (PF). B) Venn diagram showing the shared families between S. viride

416 faeces (in the left) found in the study and bacterial families of corals (Agaricia, Orbicella, Siderastrea, 
417 Porites, Diploria and Pseudodiploria where parrotfish usually feed) based on literature data (See

418 supplementary table S3) on the right.

\section{Acknowledgments}

421 Thanks to Nacor Bolaños from Corporación para el Desarrollo Sostenible del Archipiélago de San Andrés,

422 Providencia y Santa Catalina (CORALINA), and Buconos Diving Center team for the assistance during

423 field surveys; Natalia Bolaños from the Laboratorio de Ciencias Básicas Médicas at the Universidad de los

424 Andes supported the FCM analysis process. Humberto Ibarra and his team from the Centro de

425 Microscopía at the Universidad de los Andes contributed with microscopy methods and the members of

426 Laboratorio de Biología Molecular Marina team (BIOMMAR) at the Universidad de los Andes for their

427 valuable assistance.

\section{Conflicts of interest}

430 The authors declare that the research was conducted in the absence of any commercial or financial

431 relationships that could be construed as a potential conflict of interest.

\section{Reference list}

Adams LM, Cumbo VR, Takabayashi M (2009) Exposure to sediment enhances primary acquisition of Spalding HL, Smith C, Woolsey ES, Bourne DG, Bongaerts P, Hoegh-Guldberg O, Leggat W (2015) The coral core microbiome identifies rare bacterial taxa as ubiquitous endosymbionts. ISME J 9:2261-2274 Ali A, Kriefall NG, Emery LE, Kenkel CD, Matz MV, Davies SW (2019) Recruit symbiosis establishment and Symbiodiniaceae composition influenced by adult corals and reef sediment. Coral Reefs 38:405-415

Bolyen E, Rideout JR, Dillon MR, Bokulich NA, Abnet CC, Al-Ghalith GA, Alexander H, Alm EJ, Arumugam M, Asnicar F, Bai Y, Bisanz JE, Bittinger K, Brejnrod A, Brislawn CJ, Brown CT, Callahan BJ, Caraballo-Rodríguez AM, Chase J, Cope EK, Da Silva R, Diener C, Dorrestein PC, Douglas GM, Durall DM, Duvallet C, Edwardson CF, Ernst M, Estaki M, Fouquier J, Gauglitz JM, Gibbons SM, Gibson DL, Gonzalez A, Gorlick K, Guo J, Hillmann B, Holmes S, Holste H, Huttenhower C, Huttley GA, Janssen S, Jarmusch AK, Jiang L, Kaehler BD, Kang KB, Keefe CR, Keim P, Kelley ST, Knights D, Koester I, Kosciolek T, Kreps J, Langille MGI, Lee J, Ley R, Liu Y-X, Loftfield E, Lozupone C, Maher M, Marotz C, Martin BD, McDonald D, McIver LJ, Melnik AV, Metcalf JL, Morgan SC, Morton JT, Naimey AT, Navas-Molina JA, Nothias LF, Orchanian SB, Pearson T, Peoples SL, Petras D, Preuss ML, Pruesse E, Rasmussen LB, Rivers A, Robeson MS, Rosenthal P, Segata N, Shaffer M, Shiffer A, Sinha R, Song SJ, Spear JR, Swafford AD, Thompson LR, Torres PJ, Trinh P, Tripathi A, Turnbaugh PJ, Ul-Hasan $\mathrm{S}$, van der Hooft JJJ, Vargas F, Vázquez-Baeza Y, Vogtmann E, von Hippel M, Walters W, Wan Y, Wang M, Warren J, Weber KC, Williamson CHD, Willis AD, Xu ZZ, Zaneveld JR, Zhang Y, Zhu Q, Knight R, Caporaso JG (2019) Reproducible, interactive, scalable and extensible microbiome data science using QIIME 2. Nat Biotechnol 37:852-857

Bonaldo RM, Hoey AS, Bellwood DR (2014) The ecosystem roles of parrotfishes on tropical reefs. Oceanogr Mar Biol Annu Rev 52:81-132 
Bourne DG, Morrow KM, Webster NS (2016) Insights into the Coral Microbiome: Underpinning the Health and Resilience of Reef Ecosystems. Annu Rev Microbiol 70:317-340

Bourne DG, Munn CB (2005) Diversity of bacteria associated with the coral Pocillopora damicornis from the Great Barrier Reef. Environ Microbiol 7:1162-1174

Bruggemann J, van Oppen M, Breeman A (1994) Foraging by the stoplight parrotfish Sparisoma viride. I. Food selection in different, socially determined habitats. Mar Ecol Prog Ser 106:41-55

Bruggemann JH, Van Kessel AM, Van Rooij JM, Breeman AM (1996) Bioerosion and sediment ingestion by the Caribbean parrotfish Scarus vetula and Sparisoma viride: implications of fish size, feeding mode and habitat use. Mar Ecol Prog Ser 134:59-71

Burkepile DE, Adam TC, Roycroft M, Ladd MC, Munsterman KS, Ruttenberg BI (2019a) Speciesspecific patterns in corallivory and spongivory among Caribbean parrotfishes. Coral Reefs 38:417-423 Burkepile DE, Adam TC, Roycroft M, Ladd MC, Munsterman KS, Ruttenberg BI (2019b) Speciesspecific patterns in corallivory and spongivory among Caribbean parrotfishes. Coral Reefs 38:417-423 Callahan BJ, McMurdie PJ, Holmes SP (2017) Exact sequence variants should replace operational taxonomic units in marker-gene data analysis. ISME J 11:2639

Callahan BJ, McMurdie PJ, Rosen MJ, Han AW, Johnson AJA, Holmes SP (2016) DADA2: Highresolution sample inference from Illumina amplicon data. Nat Methods 13:581-583 Caporaso JG, Lauber CL, Walters WA, Berg-Lyons D, Lozupone CA, Turnbaugh PJ, Fierer N, Knight R (2011) Global patterns of 16S rRNA diversity at a depth of millions of sequences per sample. Proc Natl Acad Sci 108:4516-4522

Castro-Sanguino C, Sánchez JA (2012) Dispersal of Symbiodinium by the stoplight parrotfish Sparisoma viride. Biol Lett 8:282-286

481 Chung AE, Wedding LM, Green AL, Friedlander AM, Goldberg G, Meadows A, Hixon MA (2019) Clements KD, Angert ER, Montgomery WL, Choat JH (2014) Intestinal microbiota in fishes: what's known and what's not. Mol Ecol 23:1891-1898 Clements KD, German DP, Piché J, Tribollet A, Choat JH (2016) Integrating ecological roles and trophic diversification on coral reefs: multiple lines of evidence identify parrotfishes as microphages. Biol J Linn Soc mangrove and reef sponges. Mar Biol 126:117-123

Dunlap M, Pawlik JR (1998) Spongivory by Parrotfish in Florida Mangrove and Reef Habitats. Mar Ecol 19:325-337

Francini-Filho RB, Moura RL, Ferreira CM, Coni EO (2008) Live coral predation by parrotfishes (Perciformes: Scaridae) in the Abrolhos Bank, eastern Brazil, with comments on the classification of species into functional groups. Neotropical Ichthyol 6:191-200

Gierz S, Ainsworth TD, Leggat W (2020) Diverse symbiont bleaching responses are evident from 2degree heating week bleaching conditions as thermal stress intensifies in coral. Mar Freshw Res 71:1149 Goatley CHR, Bellwood DR (2010) Biologically mediated sediment fluxes on coral reefs: sediment removal and off-reef transportation by the surgeonfish Ctenochaetus striatus. Mar Ecol Prog Ser 415:237245

Gonzalez-Zapata FL, Bongaerts P, Ramírez-Portilla C, Adu-Oppong B, Walljasper G, Reyes A, Sanchez JA (2018) Holobiont Diversity in a Reef-Building Coral over Its Entire Depth Range in the Mesophotic Zone. Front Mar Sci 5:

Hernandez-Agreda A, Gates RD, Ainsworth TD (2017) Defining the Core Microbiome in Corals' Microbial Soup. Trends Microbiol 25:125-140 Hughes TP, Kerry JT, Álvarez-Noriega M, Álvarez-Romero JG, Anderson KD, Baird AH, Babcock RC, Beger M, Bellwood DR, Berkelmans R, Bridge TC, Butler IR, Byrne M, Cantin NE, Comeau S, Connolly SR, Cumming GS, Dalton SJ, Diaz-Pulido G, Eakin CM, Figueira WF, Gilmour JP, Harrison HB, Heron SF, Hoey AS, Hobbs J-PA, Hoogenboom MO, Kennedy EV, Kuo C, Lough JM, Lowe RJ, Liu G, McCulloch MT, Malcolm HA, McWilliam MJ, Pandolfi JM, Pears RJ, Pratchett MS, Schoepf V, Simpson 
T, Skirving WJ, Sommer B, Torda G, Wachenfeld DR, Willis BL, Wilson SK (2017) Global warming and recurrent mass bleaching of corals. Nature 543:373-377

Lesser MP, Morrow KM, Pankey SM, Noonan SHC (2018) Diazotroph diversity and nitrogen fixation in the coral Stylophora pistillata from the Great Barrier Reef. ISME J 12:813-824

Littman RA, Willis BL, Pfeffer C, Bourne DG (2009) Diversities of coral-associated bacteria differ with location, but not species, for three acroporid corals on the Great Barrier Reef. FEMS Microbiol Ecol $68: 152-163$

McMurdie PJ, Holmes S (2013) phyloseq: An R Package for Reproducible Interactive Analysis and Graphics of Microbiome Census Data. PLOS ONE 8:e61217

Meyer JL, Rodgers JM, Dillard BA, Paul VJ, Teplitski M (2016) Epimicrobiota Associated with the Decay and Recovery of Orbicella Corals Exhibiting Dark Spot Syndrome. Front Microbiol 7: Muller-Parker G (1984) Dispersal of Zooxanthellae on Coral Reefs by Predators on Cnidarians. Biol Bull 167:159-167

Mumby PJ (2009) Herbivory versus corallivory: are parrotfish good or bad for Caribbean coral reefs? Coral Reefs 28:683-690

Ngugi DK, Miyake S, Cahill M, Vinu M, Hackmann TJ, Blom J, Tietbohl MD, Berumen ML, Stingl U (2017) Genomic diversification of giant enteric symbionts reflects host dietary lifestyles. Proc Natl Acad Sci 114:E7592-E7601

Nicholson GM, Clements KD (2020) Resolving resource partitioning in parrotfishes (Scarini) using microhistology of feeding substrata. Coral Reefs 39:1313-1327

Nitschke MR, Davy SK, Ward S (2016) Horizontal transmission of Symbiodinium cells between adult and juvenile corals is aided by benthic sediment. Coral Reefs 35:335-344

Peixoto RS, Rosado PM, Leite DC de A, Rosado AS, Bourne DG (2017) Beneficial Microorganisms for Corals (BMC): Proposed Mechanisms for Coral Health and Resilience. Front Microbiol 8:

Perry CT, Kench PS, O’Leary MJ, Morgan KM, Januchowski-Hartley F (2015) Linking reef ecology to island building: Parrotfish identified as major producers of island-building sediment in the Maldives. Geology 43:503-506

Porto I, Granados C, Restrepo JC, Sanchez JA (2008) Macroalgal-associated dinoflagellates belonging to the genus Symbiodinium in Caribbean reefs. PLoS One 3:

Radax R, Rattei T, Lanzen A, Bayer C, Rapp HT, Urich T, Schleper C (2012) Metatranscriptomics of the marine sponge Geodia barretti: tackling phylogeny and function of its microbial community. Environ Microbiol 14:1308-1324

Raina J-B, Tapiolas D, Willis BL, Bourne DG (2009) Coral-Associated Bacteria and Their Role in the Biogeochemical Cycling of Sulfur. Appl Environ Microbiol 75:3492-3501

Ricci F, Marcelino VR, Blackall LL, Kühl M, Medina M, Verbruggen H (2019) Beneath the surface: community assembly and functions of the coral skeleton microbiome. Microbiome 7:159

Rotjan RD, Lewis SM (2005) Selective predation by parrotfishes on the reef coral Porites astreoides. Mar Ecol Prog Ser 305:193-201

Sanchez JA, Gil MF, Chasqui LH, Alvarado EM (2004) Grazing dynamics on a Caribbean reef-building coral. Coral Reefs 23:578-583

Shnit-Orland M, Kushmaro A (2009) Coral mucus-associated bacteria: a possible first line of defense. FEMS Microbiol Ecol 67:371-380

Strychar KB, Sammarco PW, Piva TJ (2004) Apoptotic and necrotic stages of Symbiodinium (Dinophyceae) cell death activity: bleaching of soft and scleractinian corals. Phycologia 43:768-777 Takabayashi M, Adams LM, Pochon X, Gates RD (2012) Genetic diversity of free-living Symbiodinium in surface water and sediment of Hawai ' $i$ and Florida. Coral Reefs 31:157-167 Vermeij MJ, van der Heijden RA, Olthuis JG, Marhaver KL, Smith JE, Visser PM (2013) Survival and dispersal of turf algae and macroalgae consumed by herbivorous coral reef fishes. Oecologia 171:417-425 Weber L, Gonzalez-Díaz P, Armenteros M, Apprill A (2019) The coral ecosphere: A unique coral reef habitat that fosters coral-microbial interactions. Limnol Oceanogr 64:2373-2388 Wickham H (2009) ggplot2: Elegant Graphics for Data Analysis. Springer-Verlag, New York 
bioRxiv preprint doi: https://doi.org/10.1101/2020.09.15.298737; this version posted January 15, 2021. The copyright holder for this preprint (which was not certified by peer review) is the author/funder, who has granted bioRxiv a license to display the preprint in perpetuity. It is made available under aCC-BY-NC-ND 4.0 International license. 